\title{
Prevalence and Genotyping of Human Papillomavirus among Women in the Departments of Niari and Bouenza, Republic of the Congo
}

\author{
Parfait Christy Nganga1, Luc Magloire Anicet Boumba ${ }^{1,2,3}{ }^{*}$, Candyse Paola Lemba Tsimba1, \\ Franck Gaëtan Loubanou Tchibinda4 ${ }^{4}$ Roch Bredin Bissala Nkounkou ${ }^{1}$, Eben Ebatetou Ataboho', \\ Ghislain Loubano-Voumbi', Donatien Moukassa' ${ }^{1}$ \\ ${ }^{1}$ Faculté des Sciences de la Santé, Université Marien NGOUABI, Brazzaville, Congo \\ ${ }^{2}$ Laboratoire d'Analyses Médicales et Morphologiques, Hôpital Général de Loandjili, Pointe-Noire, Congo \\ ${ }^{3}$ Zone de Recherche de Pointe-Noire, Institut National de Recherche en Science de la Santé (IRSSA), Pointe-Noire, Congo \\ ${ }^{4}$ Faculté des Sciences et Techniques, Université Marien NGOUABI, Brazzaville, Congo \\ Email: *anicetboumba1974@gmail.com
}

How to cite this paper: Nganga, P.C., Boumba, L.M.A., Lemba Tsimba, C.P., Loubanou Tchibinda, F.G., Bissala Nkounkou, R.B., Ataboho, E.E., Loubano-Voumbi, G. and Moukassa, D. (2022) Prevalence and Genotyping of Human Papillomavirus among Women in the Departments of Niari and Bouenza, Republic of the Congo. Journal of Biosciences and Medicines, 10, 64-77. https://doi.org/10.4236/jbm.2022.101007

Received: December 18, 2021

Accepted: January 18, 2022

Published: January 21, 2022

Copyright $\odot 2022$ by author(s) and Scientific Research Publishing Inc. This work is licensed under the Creative Commons Attribution International License (CC BY 4.0).

http://creativecommons.org/licenses/by/4.0/

\begin{abstract}
Human papillomaviruses (HPV) are at the origin of many mucosal, benign or malignant skin pathologies. Some so-called high-risk genotypes, especially types 16 and 18, are involved in the genesis of cervical cancer, one of the most common cancers in women. To determine the prevalence of HPV infections and to identify oncogenic genotypes circulating in the departments of Niari and Bouenza. A total of 207 cervical samples collected between 2019 and 2020 were studied. Cervico vaginal smears were performed on all samples for cytological analysis, and HPV DNA detection and genotyping were performed on GeneXpert. The average age of the women who participated in this study was $43.67 \pm 12.31$ years in Niari and $38.29 \pm 10.52$ in Bouenza with age intervals ranging from 18 to 80 years. Cytological analysis of these samples reported the following prevalences: Normal diagnosed in $89.58 \%$ (186/207) cases, ASCUS in $5.31 \%(11 / 207)$ cases, LSIL in $2.89 \%(6 / 207)$ cases, and ICC in $1.93 \%(4 / 207)$ cases. The prevalence of HPV infection was detected in $83.54 \%$ (66/186) of women without lesions, $6.32 \%$ (5/11) of ASCUS women and $10.12 \%$ (8/10) of women with cytological abnormalities [5.06\% (4/6) LSIL, and 5.06\% (4/4) ICC]. In total, 79 of the 207 women in our study tested positive for one or more HPV-HR types, or $38.16 \%$. In the department of Niari $37.5 \%(48 / 128)$ women tested positive for HPV, and in the department of Bouenza $39.24 \%$ (31/79) tested positive for HPV. Multiple infections ranged from two to more than three strains of HPV. No statistically significant association was ob-
\end{abstract}


served between socio-demographic characteristics and genotyping $(\mathrm{p}>0.05)$. On the other hand, HPV-HR prevalence varied significantly according to cervical cytology $(p=0.001)$. The results obtained show the predominance of HPV 16 in women in these two departments of Congo.

\section{Keywords}

CCU, HPV, FCV, Niari, Bouenza

\section{Introduction}

Cervical cancer is the most common cancer in women in developing countries. It is estimated to be responsible for nearly 260,000 deaths per year, about $80 \%$ of which are in developing countries [1]. In sub-Saharan Africa, it accounts for $22.2 \%$ of all cancer cases in women [2], and is the leading cause of death from female cancer in Africa behind breast cancer [3]. However, persistent infection with certain oncogenic papillomavirus (HPV) types is firmly established as the necessary cause of most precancerous and cancerous epithelial lesions of the cervix and a variable fraction of neoplastic lesions of the vulva, vagina, anus, penis and oropharynx [4].

Indeed, these HPV infections are among the most prevalent in the world [5], with a global incidence of more than 30 million new cases per year. Thus, HPV infection is one of the most common sexually transmitted viral infections [6].

In Congo, about 214 deaths from cervical cancer occur per year and are diagnosed each year (estimates for 2020) [7]. Indeed, cervical cancer ranks as the $1^{\text {st }}$ cause of death among women who die from cancer in Congo and is the $3^{\text {rd }}$ leading cause of cancer death in women aged 15 to 44 years [7], and age-adjusted incidence and mortality rates are estimated at 25.2 and 13.0 per 100,000 women, respectively [8].

In addition, the local context shows a lack of scientific information on the molecular epidemiology of HPV infections and its complications in the departments of Niari and Bouenza. This information is crucial in order to provide virological data in the category of women with normal cytology after a cervico-vaginal smear (FCV) examination, as well as in those of women with precancerous and cancerous lesions of the cervix [5], in order to be able to develop effective future strategies for the prevention and control of cervical cancer in Congo.

Thus, this study aimed to determine the prevalence of HPV infections in the departments of Niari and Bouenza, and to identify the oncogenic genotypes present.

\section{Materials and Methods}

\subsection{Type and Study Population}

This was a cross-sectional descriptive study that took place over a 21-month pe- 
riod from April 2019 to December 2020. The women included in this study were recruited from Dolisie and Nkayi General Hospitals. A total of 207 women had a Pap smear.

Cytological tests were motivated by certain gynecological problems such as bleeding, vaginal discharge, pelvic pain, pruritus or infertility exploration. Eligible patients included all women who came to the laboratory at these general hospitals for a pap smear, regardless of their medical history during the designated recruitment period. Most of them have never had a medical history regarding cervical cancer or its precancerous lesions. We excluded women who were physically or mentally unable to undergo an interview, women who were pregnant or undergoing known treatment for cervical lesions, or who had refused to participate in the study. The study protocol had been approved by the Health Sciences Research Ethics Board (HSRB): 258/MRSIT/IRSSA/CERSSA.

\subsection{Collection of Cervical Cells}

During a cervical speculum examination, samples were taken using a cytobrush of the cervix. After scraping, the cells were suspended in special collection vials containing $10 \mathrm{~mL}$ of BD SurePath solution ${ }^{\mathrm{TM}}$ and stored at $-20^{\circ} \mathrm{C}$. These samples were used for cytological and molecular analyses.

\subsection{Cytological Study}

After sampling in the different departments, the samples were sent to the pathology laboratory of the Loandjili General Hospital (HGL) in Pointe-Noire for the cytopathological study. The examination was performed by a pathologist. Results were rendered according to the Classification of the Bethesda 2001 System [9]: Normal or benign reactive cell changes (Normal/BRCC, involving any cervicitis not related to malignancy), atypical squamous cells of undetermined significance (ASCUS), low-grade intraepithelial squamous cell lesions (LSIL), high-grade squamous intraepithelial lesions (HSIL) and invasive cervical cancers (ICC).

\subsection{HPV Detection and Genotyping}

All HPV tests were performed on cervical cell samples stored in a SurePath liquid medium at the Loandjili Hospital laboratory in Pointe Noire. Identification of HPV types was performed by real-time PCR using geneXpert technology (CEPHEID), USA from the Xpert ${ }^{\circledR}$ HPV kit.

The Xpert HPV Assay test is an automated test for the qualitative detection and differentiation of HPV DNA by pooled molecular typing, including high-risk oncogenic HPV. This detection was done by differentiation of the presence of an HPV-16 genotype alone, by grouped genotyping of HPV-18/45 types, grouped genotyping of types 16/18/45 and by detection of high-risk HPV types other than 16,18 , and 45 . Extraction, amplification and detection are automated and last 60 minutes. 


\subsection{Statistical Analyses}

Statistical significance between HPV genotypes, cytological status and sociodemographic characteristics was assessed by the exact Fisher test or the Khie-2 test using Epi-Info version 7 software (https://www.cdc.gov/epiinfo/fra/fr_pc.html). Meaning was defined as $\mathrm{p}<0.05$ for all tests.

\section{Results}

\subsection{Socio-Demographic Characteristics}

A total of 207 cervical samples were analyzed, including 128 from the department of Niari and 79 from the department of Bouenza. The average age of women was $43.67 \pm 12.31$ years and $38.29 \pm 10.52$ years respectively in the departments of Niari and Bouenza with extremes ranging from 18 to 80 years.

Socio-demographic characteristics are shown in Table 1. The main local risk factors related to HPV infection studied in women in these departments were: age, age of first sexual intercourse, number of sexual partners and gestures, taking oral contraceptives, smoking. No significant association was observed between socio-demographic characteristics and genotyping in our study population $(\mathrm{p}>0.05)$.

\subsection{Cytological Profile}

The cytological profile by department (Table 2) was as follows:

- The department of Niari, with $92.19 \%$ (118/128) of cases of normal cytology, 2.34\% (3/128) cases of ASCUS, 2.34\% (3/128) cases of LSIL and 3.13\% (4/128) ICC cases.

- The Department of Bouenza defined the following cytological profile: $86.07 \%$ (68/79) of normal cytology cases, $10.12 \%$ (8/79) of ASCUS cases and $3.79 \%$ (3/79) of cases were LSIL.

\subsection{Genotyping of HPV-HR}

A total of 79 of the 207 women in our study tested positive for one or more HPV-HR types. The genotypic distribution by department is shown in Table 3. In the department of Niari 48 (37.5\%) women tested positive for HPV, and in the department of Bouenza 31 (39.24\%) women tested positive for HPV. Multiple infections ranged from two to more than three strains of HPV.

\subsection{Bivariate Analysis}

\subsubsection{HPV Infection and Socio-Demographic Characteristics}

In the department of Niari $43.9 \%$ of women with high-risk HPV infection were between 30 and 40 years old. Of the $87.5 \%$ of women who had their first sexual intercourse before the age of $18,37.5 \%$ had an HPV-HR infection. Women who had more than 5 sexual partners had $43.75 \%$ HPV-HR carrying. HPV-HR infection was observed in $37.07 \%$ of women who had more than 5 pregnancies compared to $42.85 \%$ in those who had less than 5 pregnancies. 
Table 1. Socio-demographic characteristics in the department of Niari and Bouenza.

\begin{tabular}{|c|c|c|c|c|}
\hline \multirow[b]{2}{*}{ Characteristics } & \multicolumn{2}{|c|}{ Department of Niari } & \multicolumn{2}{|c|}{ Department of Bouenza } \\
\hline & $\begin{array}{l}\text { Participants } \\
\text { (n) }\end{array}$ & $\begin{array}{c}\text { Percentage } \\
(\%)\end{array}$ & $\begin{array}{l}\text { Effective } \\
\text { (n) }\end{array}$ & $\begin{array}{l}\text { Percentage } \\
(\%)\end{array}$ \\
\hline \multicolumn{5}{|l|}{ Age group (years) } \\
\hline$<30$ & 18 & 14.06 & 12 & 15.18 \\
\hline $30-40$ & 41 & 32.03 & 38 & 48.1 \\
\hline $40-50$ & 31 & 24.21 & 19 & 24.05 \\
\hline$>50$ & 38 & 29.68 & 10 & 12.65 \\
\hline \multicolumn{5}{|c|}{$\begin{array}{c}\text { First sexual intercourse age } \\
\text { (years) }\end{array}$} \\
\hline$<18$ & 112 & 87.5 & 49 & 62.02 \\
\hline$\geq 18$ & 16 & 12.5 & 30 & 37.97 \\
\hline \multicolumn{5}{|c|}{ Number of Sexual partners } \\
\hline$<5$ & 96 & 75 & 41 & 51.89 \\
\hline$\geq 5$ & 32 & 25 & 38 & 48.1 \\
\hline \multicolumn{5}{|c|}{ Number of pregnancies } \\
\hline None $(0)$ & 4 & 3.12 & 6 & 7.59 \\
\hline$<5$ & 35 & 27.34 & 32 & 40.5 \\
\hline$\geq 5$ & 89 & 69.53 & 41 & 51.89 \\
\hline \multicolumn{5}{|l|}{ Level of Education } \\
\hline Primary & 13 & 10.15 & 15 & 18.98 \\
\hline Secondary & 85 & 66.4 & 47 & 59.49 \\
\hline University & 30 & 23.43 & 17 & 21.51 \\
\hline \multicolumn{5}{|l|}{ Marital Status } \\
\hline Singles & 70 & 54.68 & 33 & 41.77 \\
\hline Maried & 47 & 36.71 & 34 & 43.03 \\
\hline Divorced/Widows & 11 & 8.59 & 12 & 15.18 \\
\hline \multicolumn{5}{|l|}{ Current Smoke } \\
\hline Yes & 8 & 6.25 & 3 & 3.79 \\
\hline No & 120 & 93.75 & 76 & 96.2 \\
\hline \multicolumn{5}{|l|}{ Alcoholic status } \\
\hline Yes & 77 & 60.15 & 41 & 51.89 \\
\hline No & 51 & 39.84 & 38 & 48.1 \\
\hline \multicolumn{5}{|c|}{ Oral Contraception use } \\
\hline Yes & 55 & 57.03 & 6 & 7.59 \\
\hline No & 73 & 42.96 & 73 & 92.4 \\
\hline
\end{tabular}


Table 2. Distribution of the cytological profile by department.

\begin{tabular}{ccccc}
\hline & \multicolumn{2}{c}{ Niari Department } & \multicolumn{2}{c}{ Bouenza Department } \\
\cline { 2 - 5 } Cytology & $\begin{array}{c}\text { Participants } \\
(\mathrm{n})\end{array}$ & $\begin{array}{c}\text { Percentage } \\
(\%)\end{array}$ & $\begin{array}{c}\text { Participants } \\
(\mathrm{n})\end{array}$ & $\begin{array}{c}\text { Percentage } \\
(\%)\end{array}$ \\
\hline Normal & 118 & 92.19 & 68 & 86.07 \\
Ascus & 3 & 2.34 & 8 & 10.12 \\
LSIL & 3 & 2.34 & 3 & 3.79 \\
HSIL & 0 & 0 & 0 & 0 \\
ICC & 4 & 3.13 & 0 & 0 \\
\hline
\end{tabular}

ASCUS: Atypies of squamous cells of undetermined significance. LSIL: Low-grade squamous intraepithelial lesion. HSIL: High-grade scaly intraepithelial lesion. ICC: Invasive cervical carcinoma.

Table 3. Prevalence of HPV types by department.

\begin{tabular}{ccccc}
\hline \multirow{2}{*}{$\begin{array}{c}\text { Génotypes } \\
\text { HPV }\end{array}$} & \multicolumn{2}{c}{ Niari Department $(\mathrm{N}=128)$} & \multicolumn{2}{c}{ Bouenza Department $(\mathrm{N}=79)$} \\
\cline { 2 - 5 } Participants (n) & Percentage (\%) & Participants (n) & Percentage (\%) \\
\hline HPV- & 80 & 62.5 & 48 & 60.75 \\
HPV+ & 48 & 37.5 & 31 & 39.24 \\
16 & 24 & 18.75 & 17 & 21.51 \\
$18 / 45$ & 4 & 3.12 & 1 & 1.26 \\
$16 / 18 / 45$ & 2 & 1.56 & 2 & 2.52 \\
16/Other & 8 & 6.24 & 7 & 8.86 \\
Other & 10 & 7.81 & 4 & 5.04 \\
\hline
\end{tabular}

No statistically significant differences were observed between socio-demographic characteristics and HPV-HR genotyping $(\mathrm{p}>0.05)$. All results are reported in Table 4.

In the department of Bouenza, it was observed a portage of HPV-HR infection in $39.47 \%$ of cases in 30 - 40 year olds. $38.77 \%$ of HPV-HR infection was observed in women who had their first sexual intercourse before the age of 18 . Women who had more than 5 sexual partners reported an infection $39.47 \%$ while those who had more than 5 pregnancies were infected only to the rate of $36.58 \%$.

No statistically significant association was observed between socio-demographic characteristics and HPV genotyping $(\mathrm{p}>0.05)$. All the results are reported in Table 5 .

\subsubsection{HPV Infection and Cytological Diagnosis}

Bivariate analysis between HPV-HR infection carriage and cytological profile in Niari department showed that $85.41 \%$ of women with normal cytology had HPV-HR infection. Carriage of HPV-HR infection was $4.16 \%$ in women with ASCUS and $10.41 \%$ in those with cytological abnormalities, including $2.08 \%$ LSIL and $8.33 \%$ ICC. A statistically significant association was observed ( $p=$ 
0.013). Table 6 shows the prevalence of HPV-HR infection according to the cytological profile in the department of Niari.

Table 4. Socio-demographic characteristics and HPV infection in the department of Niari.

\begin{tabular}{|c|c|c|c|c|c|c|}
\hline \multirow{3}{*}{ Characteristics } & \multirow{2}{*}{\multicolumn{2}{|c|}{ Participants }} & \multicolumn{4}{|c|}{ Department of Niari } \\
\hline & & & \multicolumn{2}{|c|}{$\mathrm{HPV}(+)$} & \multicolumn{2}{|c|}{ HPV (-) } \\
\hline & $\mathbf{n}$ & $\%$ & $\mathbf{n}$ & $\%$ & $\mathbf{n}$ & $\%$ \\
\hline \multicolumn{7}{|l|}{ Age group (years) } \\
\hline$<30$ & 18 & 14.06 & 4 & 22.22 & 14 & 77.77 \\
\hline $30-40$ & 41 & 32.03 & 18 & 43.9 & 23 & 56.09 \\
\hline $40-50$ & 31 & 24.21 & 13 & 41.93 & 18 & 58.06 \\
\hline$>50$ & 38 & 29.68 & 13 & 34.21 & 25 & 65.78 \\
\hline \multicolumn{7}{|c|}{ First sexual intercourse age (years) } \\
\hline$<18$ & 112 & 87.5 & 42 & 37.5 & 70 & 62.5 \\
\hline$\geq 18$ & 16 & 12.5 & 6 & 37.5 & 10 & 62.5 \\
\hline \multicolumn{7}{|c|}{ Number of Sexual partners } \\
\hline$<5$ & 96 & 75 & 34 & 35.41 & 62 & 64.58 \\
\hline$\geq 5$ & 32 & 25 & 14 & 43.75 & 18 & 56.25 \\
\hline \multicolumn{7}{|c|}{ Number of pregnancies } \\
\hline None (0) & 4 & 3.12 & 0 & 0 & 4 & 100 \\
\hline$<5$ & 35 & 27.34 & 15 & 42.85 & 20 & 57.14 \\
\hline$\geq 5$ & 89 & 69.53 & 33 & 37.07 & 56 & 62.92 \\
\hline \multicolumn{7}{|l|}{ Level of Education } \\
\hline Primary & 13 & 10.15 & 7 & 53.84 & 6 & 46.15 \\
\hline Secondary & 85 & 66.4 & 28 & 32.94 & 57 & 67.05 \\
\hline University & 30 & 23.43 & 13 & 43.33 & 17 & 56.66 \\
\hline \multicolumn{7}{|l|}{ Marital Status } \\
\hline Singles & 70 & 54.68 & 26 & 37.14 & 44 & 62.85 \\
\hline Married & 47 & 36.71 & 17 & 36.17 & 30 & 63.82 \\
\hline Divorced/Widows & 11 & 8.59 & 6 & 54.54 & 5 & $45 ., 45$ \\
\hline \multicolumn{7}{|l|}{ Current Smoke } \\
\hline Yes & 8 & 6.25 & 2 & 25 & 6 & 75 \\
\hline No & 120 & 93.75 & 46 & 38.33 & 74 & 61.66 \\
\hline \multicolumn{7}{|l|}{ Alcoholic status } \\
\hline Yes & 77 & 60.15 & 30 & 38.96 & 47 & 61.03 \\
\hline No & 51 & 39.84 & 18 & 35.29 & 33 & 64.7 \\
\hline \multicolumn{7}{|c|}{ Oral Contraception use } \\
\hline Yes & 55 & 57.03 & 16 & 29.09 & 39 & 70.9 \\
\hline No & 73 & 42.96 & 32 & 43.83 & 41 & 56.16 \\
\hline
\end{tabular}

$\mathrm{p}>0.05$. 
Table 5. Socio-demographic characteristics and HPV infection in the department of Bouenza.

\begin{tabular}{|c|c|c|c|c|c|c|}
\hline \multirow{3}{*}{ Characteristics } & \multirow{2}{*}{\multicolumn{2}{|c|}{ Participants }} & \multicolumn{4}{|c|}{ Department of Bouenza } \\
\hline & & & \multicolumn{2}{|c|}{$\operatorname{HPV}(+)$} & \multicolumn{2}{|c|}{ HPV (-) } \\
\hline & $\mathbf{n}$ & $\%$ & $\mathrm{n}$ & $\%$ & $\mathbf{n}$ & $\%$ \\
\hline \multicolumn{7}{|l|}{ Age group (years) } \\
\hline$<30$ & 12 & 15.18 & 4 & 33.33 & 8 & 66.66 \\
\hline $30-40$ & 38 & 48.1 & 15 & 39.47 & 23 & 60.52 \\
\hline $40-50$ & 19 & 24.05 & 8 & 42.1 & 11 & 57.89 \\
\hline$>50$ & 10 & 12.65 & 4 & 40 & 6 & 60 \\
\hline \multicolumn{7}{|c|}{$\begin{array}{c}\text { First sexual intercourse age } \\
\text { (years) }\end{array}$} \\
\hline$<18$ & 49 & 62.02 & 19 & 38.77 & 30 & 61.22 \\
\hline$\geq 18$ & 30 & 37.97 & 12 & 40 & 18 & 60 \\
\hline \multicolumn{7}{|c|}{ Number of Sexual partners } \\
\hline$<5$ & 41 & 51.89 & 16 & 39.02 & 25 & 60.97 \\
\hline$\geq 5$ & 38 & 48.1 & 15 & 39.47 & 23 & 60.52 \\
\hline \multicolumn{7}{|c|}{ Number of pregnancies } \\
\hline None $(0)$ & 6 & 7.59 & 2 & 33.33 & 4 & 66.66 \\
\hline$<5$ & 32 & 40.5 & 14 & 43.75 & 18 & 56.25 \\
\hline$\geq 5$ & 41 & 51.89 & 15 & 36.58 & 26 & 63.41 \\
\hline \multicolumn{7}{|l|}{ Level of Education } \\
\hline Primary & 15 & 18.98 & 5 & 33.33 & 10 & 66.66 \\
\hline Secondary & 47 & 59.49 & 20 & 42.55 & 27 & 57.44 \\
\hline University & 17 & 21.51 & 6 & 35.29 & 11 & 64.7 \\
\hline \multicolumn{7}{|l|}{ Marital Status } \\
\hline Singles & 33 & 41.77 & 13 & 39.39 & 20 & 60.6 \\
\hline Married & 34 & 43.03 & 13 & 38.23 & 21 & 61.76 \\
\hline Divorced/Widows & 12 & 15.18 & 5 & 41.66 & 7 & 58.33 \\
\hline \multicolumn{7}{|l|}{ Current Smoke } \\
\hline Yes & 3 & 3.79 & 3 & 100 & 0 & 0 \\
\hline No & 76 & 96.2 & 28 & 36.84 & 48 & 63.15 \\
\hline \multicolumn{7}{|l|}{ Alcoholic status } \\
\hline Yes & 41 & 51.89 & 19 & 46.34 & 22 & 53.65 \\
\hline No & 38 & 48.1 & 12 & 31.57 & 26 & 68.42 \\
\hline \multicolumn{7}{|l|}{ Oral Contraception use } \\
\hline Yes & 6 & 7.59 & 2 & 33.33 & 4 & 66.66 \\
\hline No & 73 & 92.4 & 29 & 39.72 & 44 & 60.27 \\
\hline
\end{tabular}


Table 6. Genotyping of HPV-HR and cytological status in the department of Niari.

\begin{tabular}{|c|c|c|c|c|c|c|c|c|c|c|c|c|}
\hline \multirow{3}{*}{ HPV types } & \multicolumn{12}{|c|}{ Cytological profil } \\
\hline & \multicolumn{2}{|c|}{$\begin{array}{c}\text { Department } \\
\text { of Niari }\end{array}$} & \multicolumn{2}{|c|}{ Normal } & \multicolumn{2}{|c|}{ ASCUS } & \multicolumn{2}{|c|}{ LSIL } & \multicolumn{2}{|c|}{ HSIL } & \multicolumn{2}{|c|}{ ICC } \\
\hline & $\mathbf{N}$ & $\%$ & $\mathbf{n}$ & $\%$ & $\mathbf{n}$ & $\%$ & $\mathbf{n}$ & $\%$ & $\mathrm{n}$ & $\%$ & $\mathrm{n}$ & $\%$ \\
\hline HPV- & 80 & 62.5 & 77 & 96.25 & 1 & 1.25 & 2 & 2.5 & 0 & 0 & 0 & 0 \\
\hline HPV+ & 48 & 37.5 & 41 & 85.41 & 2 & 4.16 & 1 & 2.08 & 0 & 0 & 4 & 8.33 \\
\hline 16 & 24 & 18.75 & 22 & 45.82 & 1 & 2.08 & 0 & 0 & 0 & 0 & 1 & 2.08 \\
\hline $18 / 45$ & 4 & 3.12 & 2 & 4.16 & 0 & 0 & 1 & 2.08 & 0 & 0 & 1 & 2.08 \\
\hline $16 / 18 / 45$ & 2 & 1.56 & 2 & 4.16 & 0 & 0 & 0 & 0 & 0 & 0 & 0 & 0 \\
\hline 16/Other & 8 & 6.24 & 6 & 12.49 & 1 & 2.08 & 0 & 0 & 0 & 0 & 1 & 2.08 \\
\hline Other & 10 & 7.81 & 9 & 18.74 & 0 & 0 & 0 & 0 & 0 & 0 & 1 & 2.08 \\
\hline
\end{tabular}

$\mathrm{P}=0.013$.

Bivariate analysis between HPV-HR infection carriage and cytological profile in Bouenza department showed that $80.64 \%$ of women with normal cytology had HPV-HR infection. Carriage of HPV-HR infection was $9.67 \%$ in women with ASCUS and LSIL respectively. A statistically significant association was observed $(\mathrm{p}=0.039)$. Table 7 shows the prevalence of HPV-HR infection according to the cytological profile in the department of Bouenza.

\section{Discussion}

Epidemiological data on HPV strain genotyping and cervical cancer remain fragmented in the Republic of the Congo. This information on HPV infections is essential in the process of implementing a national HPV control program. The objective of this work was to determine the prevalence of HPV infections in two departments of the Congo, and to identify the oncogenic genotypes according to cytological status.

The average age of the women participating in this study was $43.67 \pm 12.31$ years in Niari and $38.29 \pm 10.52$ in Bouenza with age intervals ranging from 18 to 80 years.

Our results for the department of Niari are similar to those of Boumba et al. (2015), Loubanou Tchibinda et al. (2020) and Mehendar Porika et al. (2011) which reported the average ages of $44.3 \pm 8.2$ years, $43.74 \pm 10.30$ years and 47.9 \pm 1.8 years [10] [11] [12] respectively. On the other hand, our average age for the department of Bouenza is also in agreement with that of Reesink-Peters et al. (2004) who obtained an average age population of 37 years in the Netherlands [13]. These similarities in the average age of the study population could be explained by the fact that the dynamics of the Congolese population have remained the same for the last 5 years.

In the departments of Niari and Bouenza, $87.5 \%$ and $62.02 \%$ of women had their first sexual intercourse before the age of 18 , respectively. These results are 
Table 7. Genotyping of HPV-HR and cytological status in the department of Bouenza.

\begin{tabular}{|c|c|c|c|c|c|c|c|c|c|c|c|c|}
\hline \multirow{3}{*}{ types HPV } & & & \multicolumn{10}{|c|}{ Cytology } \\
\hline & \multicolumn{2}{|c|}{$\begin{array}{l}\text { Department } \\
\text { of Bouenza }\end{array}$} & \multicolumn{2}{|c|}{ Normal } & \multicolumn{2}{|c|}{ ASCUS } & \multicolumn{2}{|c|}{ LSIL } & \multicolumn{2}{|c|}{ HSIL } & \multicolumn{2}{|c|}{ ICC } \\
\hline & $\mathbf{N}$ & $\%$ & $\mathrm{n}$ & $\%$ & $\mathbf{n}$ & $\%$ & $\mathbf{n}$ & $\%$ & $\mathrm{n}$ & $\%$ & $\mathbf{n}$ & $\%$ \\
\hline HPV- & 48 & 60.75 & 43 & 89.58 & 5 & 10.41 & 0 & 0 & 0 & 0 & 0 & 0 \\
\hline HPV+ & 31 & 39.24 & 25 & 80.64 & 3 & 9.67 & 3 & 9.67 & 0 & 0 & 0 & 0 \\
\hline 16 & 17 & 21.51 & 15 & 48.38 & 2 & 6.44 & 0 & 0 & 0 & 0 & 0 & 0 \\
\hline $18 / 45$ & 1 & 1.26 & 0 & 0 & 0 & 0 & 1 & 3.22 & 0 & 0 & 0 & 0 \\
\hline $16 / 18 / 45$ & 2 & 2.53 & 1 & 3.22 & 1 & 3.22 & 0 & 0 & 0 & 0 & 0 & 0 \\
\hline 16/Other & 7 & 8.88 & 6 & 19.35 & 0 & 0 & 1 & 3.22 & 0 & 0 & 0 & 0 \\
\hline Other & 4 & 5.06 & 3 & 9.67 & 0 & 0 & 1 & 3.22 & 0 & 0 & 0 & 0 \\
\hline
\end{tabular}

slightly lower than those of Catarino et al. (2016) in Cameroon, Arora et al. (2005) in England [14] [15], who had found the age of 19 in the majority of their studies. On the other hand Shin et al. (2019) had reported an average age of 17 years in India [16]. The precocity of the age of the first sexual intercourse seems to be explained by the culture and the sociology of the Congolese population which is very modern, young and very Westernized in mentality.

In the present study, $25 \%$ of women in the department of Niari and $48.1 \%$ of that of Bouenza had more than 5 sexual partners. These results can be superimposed on that of Carol Chelimo [17]. Regardless of the department, more than $51 \%$ of the women had at least 5 pregnancies. This result is close to that of Olivier et al. (2005) who obtained $59.6 \%$ in an epidemiological and cytopathological profile study of dysplastic lesions of the cervix in Congo-Kinshasa [18]. The modernization of manners and the precocity of the age of the first sexual intercourse are as many factors explaining the multiplicity of sexual partners. However, the level of poverty in the population also plays a major role in this sense.

The cytological profile in the departments of Niari and Bouenza was respectively $92.19 \%$ and $86.07 \%$ of normal cytology; $2.34 \%$ and $10.12 \%$ ASCUS; $2.34 \%$ and $3.79 \%$ LSIL. Only $3.13 \%$ of CCI was found in the department of Niari. Our results are similar to those of Kasap et al. (2011) who found in their studies a rate of $10.85 \%$ of abnormal pap smears in Turkey [19], and Takamatsu et al. (2017) reported a prevalence of $14.57 \%$ of cytological abnormalities in Nigeria [20].

On the other hand, Vjosa et al. (2017) had reported much higher results with prevalences of $49.93 \%$ in Macedonia [21]. While cervical cancer is the 2nd cancer in Congolese women, only $12.35 \%$ of our study population had a cytological abnormality. This relatively low rate could be explained by the young nature of our population which is able thanks to a strong local immunity to spontaneously eliminate the virus [22]. 
The prevalence of HPV-HR infection was $37.5 \%$ and $39.24 \%$ in the departments of Niari and Bouenza respectively. These results are similar to those of BOUMBA et al. (2015) and LOUBANOU et al. (2020) which reported prevalences of $41.1 \%$ and $41.5 \%$ respectively [23] [24]. On the other hand, they do not agree with Gordana Kovacevic's study in Serbia which was 51.8\% [25], and are also much higher than those described in the majority of European studies which are between $11.3 \%$ and $18.3 \%$ [26]. Our HPV prevalence observed in the two departments, although low compared to certain African countries, show higher proportions than the African average. The types of HPV-HR observed in this study allow us to confirm the importance of screening in these populations studied.

The prevalence of HPV infection in women without cervical lesions was $85.41 \%$ and $80.64 \%$ respectively in Niari and Bouenza. These HPV-HR frequencies in women without cervical lesions were well above the global average $(10.4 \%)$, higher than the average in the sub-Saharan Africa region $(22.1 \%)$ and finally higher than the Boumba et al. study (2015) (23.5\%) [23] [27].

Indeed, the exposure of our study population to many risk factors for HPV infection and risky sexual behaviors could explain this high rate of HPV infection observed in these two departments. These results also show the lack of knowledge of HPV infection in our population, which is rarely detected. The lack of a national screening program and awareness campaigns could also explain this lack of knowledge and high rates of HPV-HR in this category of women. On the other hand, $14.54 \%$ and $19.34 \%$ of women with HPV-HR infection had at least one cytological abnormality in the departments of Niari and Bouenza respectively. These results in agreement with the majority of studies in the literature prove the lack of information and awareness among populations about this pathology and suggest that women who consult are potentially at risk because they do so for the most part only as a result of a gynecological problem.

In both departments, HPV 16 was the most prevalent genotype, $45.82 \%$ in Niari and $48.38 \%$ in Bouenza. These results are in agreement with the study by LOUBANOU et al. (2020) which placed HPV 16 in first place, and other types of HPV in second place [24]. They also agree with the study by BOUMBA et al. (2015) on the distribution of HPV whose genotypes HPV 16 (20.6\%) and HPV $33(14.3 \%)$ were the most prevalent [23]. Although these results allowed us to obtain the prevalence of HPV 16 isolation genotypes, the GeneXpert technique used in this study did not allow us to determine the prevalence of other HPV types, due to the fact that this typing is pooled.

High-risk oncogenic HPV genotypes have been observed in low-grade, highgrade and invasive cervical cancers. These results are consistent with the study by N. El Gnaoui et al. [28].

These high prevalences confirm how aggressive HPV 16 is compared to other types and reinforce the idea of establishing better epidemiological monitoring of the populations of these two departments in order to prevent the persistence and progression of these HPV-HR to cervical cancer [23] [24]. 
It should be noted that this study, despite its limitations related to sample size, presents a pragmatic situational analysis of the molecular epidemiology of this virus in the two departments concerned.

\section{Conclusion}

The present study made it possible to define the cytological profile of precancerous and cancerous lesions of the cervix in the departments of Niari and Bouenza. Our results showed that despite the absence of cytological lesions, more than $50 \%$ of HPV-HR were identified in women with normal cytology with HPV type 16 as the most prevalent. This work is a reminder of the importance of the urgent establishment of a national program to fight against this cancer and HPV infections in Congo. However, future studies are needed to map HPV-HR throughout the national territory.

\section{Acknowledgements}

We would like to thank the HDL Laboratory Management of the Marie Madeleine GOMBES foundation. Our thanks also go to Doctor Francis TCHYCAYA for the multifaceted support.

\section{Conflicts of Interest}

The authors declare no conflicts of interest regarding the publication of this paper.

\section{References}

[1] Bray, F., Ferlay, J., Soerjomataram, I., et al. (2018) Global Cancer Statistics 2018: GLOBOCAN Estimates of Global Incidence and Mortality for 36 Cancers in 185 Countries. CA: A Cancer Journal for Clinicians, 68, 394-424.

https://doi.org/10.3322/caac.21492

[2] Anorlu, R.I. (2008) Cervical Cancer: The Sub-Saharan African Perspective. Reproductive Health Matters, 16, 41-49. https://doi.org/10.1016/S0968-8080(08)32415-X

[3] Ferlay, J., Soerjomataram, D.R., Eser, S., Mathers, C., et al. (2012) Global Cancer Incidence and Mortality: Sources, Methods and Key Models. Globocan.

[4] Sangwa-Lugoma, G., Ramanakumar, A.V., Mahmud, S., et al. (2011) Prevalence and Determinants of High-Risk Human Papillomavirus Infection in Women from a Sub-Saharan African Community. Sexually Transmitted Diseases, 38, 308-315. https://doi.org/10.1097/OLQ.0b013e3181fc6ec0

[5] Ferlay, J., Colombet, M., Soerjomataram, I., et al. (2019) Estimating the Global Cancer Incidence and Mortality in 2018: GLOBOCAN Sources and Methods. International Journal of Cancer, 144, 1941-1953. https://doi.org/10.1002/ijc.31937

[6] De Vuyst, H., Alemany, L., Lacey, C., et al. (2013) The Burden of Human Papillomavirus Infections and Related Diseases in Sub-Saharan Africa. Vaccine, 31, F32-F46. https://doi.org/10.1016/j.vaccine.2012.07.092

[7] Bruni, L., Albero, G., Serrano, B., et al. (2021) ICO/IARC Information Centre on HPV and Cancer (HPV Information Centre). Human Papillomavirus and Related Diseases in Congo. Summary Report 22 October. 
[8] Bruni, L., Barrionuevo-Rosas, L., Albero, G., et al. (2018) ICO/IARC Information Centre on HPV and Cancer (HPV Information Centre). Human Papillomavirus and Related Diseases Worldwide. Synthesis Report of 27 July 2017.

[9] Apgar, B.S., Zoschnick, L., Wright, T.C., et al. (2003) The 2001 Bethesda System Terminology. American Family Physician, 68, 1992-1998.

[10] Boumba, L.M.A., Hilali, L., Mouallif, M., et al. (2014) Specific Genotypes of Human Papillomavirus in 125 High-Grade Squamous Lesions and Invasive Cervical Cancer Cases from Congolese Women. BMC Public Health, 14, Article No. 1320. https://doi.org/10.1186/1471-2458-14-1320

[11] Loubano-Voumbi, G., et al. (2020) Distribution of HPV Strains in HIV-Positive Women in Pointe-Noire and Dolisie (Congo). International Journal of Virology and Molecular Biology, 9, 45-49.

[12] Porika, M., Radhika, T., Anwar, M., et al. (2011) Evaluation of Reverse Transcriptase of Human Serum Telomerase as a Novel Marker of Cervical Cancer. The International Journal of Biological Markers, 26, 22-26.

https://doi.org/10.5301/JBM.2011.6352

[13] Reesink-Peters, J.F.S., Roderick, H.J.B., Thomas, G.S., et al. (2004) Elevated hTERT mRNA Levels: A Potential Determinant of Bronchial Squamous Cell Carcinoma (in Situ). International Journal of Cancer, 109, 412-417.

https://doi.org/10.1002/ijc.11732

[14] Catarino, R., Vassilakos, P., Tebeu, et al. (2016) Risk Factors Associated with the Prevalence of Human Papillomavirus and Cervical Neoplasia in Cameroonian Women. Cancer Epidemiology, 40, 60-66.

https://doi.org/10.1016/j.canep.2015.11.008

[15] Arora, R., Kumar, A., Prusty, et al. (2005) Prevalence of High-Risk Human Papillomavirus (HPV-HR) Types 16 and 18 in Healthy Women with a Cytologically Negative Smear. European Journal of Obstetrics \& Gynecology and Reproductive Biology, 121, 104-109. https://doi.org/10.1016/j.ejogrb.2004.11.025

[16] Shin, S.S., Carpenter, C.L., Ekstrand, M.L., et al. (2019) Cervical Cancer Awareness and Presence of Abnormal Cytology in HIV-Infected Women on Antiretroviral Therapy in Rural Andhra Pradesh, India. International Journal of STDs and AIDS, 30, 586-595. https://doi.org/10.1177/0956462419825950

[17] Chelimo, C., Wouldes, T.A., et al. (2013) Risk Factors for and Prevention of Human Papillomaviruses (HPV), Genital Warts and Cervical Cancer. Journal of Infection, 66, 207-217. https://doi.org/10.1016/j.jinf.2012.10.024

[18] Olivier, N., Fabrice, K., Albert, et al. (2021) Epidemiological and Cytopathological Profile of Dysplastic Lesions of the Cervix in South Kivu/Congo. Open Journal of Obstetrics and Gynecology, 11, 162-182. https://doi.org/10.4236/ojog.2021.112018

[19] Kasap, B., Yetimalar, H., Keklik, A., et al. (2011) Prevalence and Risk Factors for Human Papillomavirus DNA in Cervical Cytology. European Journal of Obstetrics \& Gynecology and Reproductive Biology, 159, 168-171. https://doi.org/10.1016/j.ejogrb.2011.06.021

[20] Takamatsu, R., Nabandith, V., Pholsena, V., et al. (2017) Cervical Cytology and HPV among Asymptomatic Female Volunteers in Vietnam, Lao PDR. BMC Cancer, 17, Article No. 872. https://doi.org/10.1186/s12885-017-3900-6

[21] Zejnullahu, V.A. and Valon, A. (2017) Correlation of hTERT Expression with Cervical Cytological Abnormalities and HPV Infection. Medical Sciences, 3, 143-151.

[22] Denis, F., Hanz, S. and Alain, S. (2008) Clearance, Persistence and Recurrence of Papillomavirus Infection. Gynecology Obstetrics \& Fertility, 36, 430-440. 
https://doi.org/10.1016/j.gyobfe.2008.02.008

[23] Boumba, L.M.A., Qmichou, Z., Mouallif, M., et al. (2015) Distribution of Human Papillomavirus Genotypes by Cervical Cytological Status in Women Attending Loandjili General Hospital, Pointe-Noire, South-West Congo (Brazzaville). Journal of Medical Virology, 87, 1769-1776. https://doi.org/10.1002/jmv.24221

[24] Tchibinda, F.G.L., Boumba, L.M.A. and Ngatali, S.F.C. (2020) Molecular Characterization of Oncogenic HPVs by Genexpertin Congolese Women in the Cities of Pointe-Noire and Dolisie. Journal of Global Biosciences, 9, 7980-7987.

[25] Kovacevic, G., Milosevic, V., Knezevic, P., et al. (2019) Prevalence of Oncogenic Human Papillomavirus and Genetic Diversity in the L1 Gene of HPV16 HPV 18 HPV 31 and HPV33 Found in Women from Vojvodina Province Serbia. Biologicals, 58, 57-63. https://doi.org/10.1016/j.biologicals.2019.02.001

[26] Bosch, F.X., Burchell, A.N., Schiffman, M., et al. (2008) Epidemiology and Natural History of Human Papillomavirus Infections and Type-Specific Implications in Cervical Neoplasia. Vaccine, 26, K1-K16.

https://doi.org/10.1016/j.vaccine.2008.05.064

[27] Smith, J.S., Lindsay, L., Hoots, B., et al. (2007) Human Papillomavirus Type Distribution in Invasive Cervical Cancer and High-Grade Cervical Lesions: A Meta-Analysis Update. International Journal of Cancer, 121, 621-632. https://doi.org/10.1002/ijc.22527

[28] El Gnaoui, N., Joutei, H.A.H., Saile, R., et al. (2013) Molecular Diagnosis of Human Papillomavirus Infection in Precancerous Lesions of the Cervix. African Journal of Cancer, 5, 73-78. https://doi.org/10.1007/s12558-013-0248-y 